\title{
Viability of calanoid copepod eggs from intertidal sediments: a comparison of three estuaries
}

\author{
J. A. Lindley*, C. L. George, S. V. Evans, P. Donkin \\ Natural Environment Research Council, Plymouth Marine Laboratory, West Hoe, Plymouth PL1 3DH, United Kingdom
}

\begin{abstract}
Calanoid copepod nauplii hatched from intertidal sediment samples from 3 British estuaries, the Exe, the Humber and the Mersey. The Exe estuary is exposed to low levels of urban and agricultural pollution but the Humber and Mersey are subject to more extensive urban and industrial pollution. Samples were taken from the Humber and the Exe in April and November 1995 and from the Mersey and the Exe in June and October 1995. The concentrations of polycyclic aromatic hydrocarbons $(\mathrm{PAH})$ in the sediments were measured as an index of pollution. The PAH concentrations in sediment were lowest in the Exe (mean $<100 \mu \mathrm{g} \mathrm{g}^{-1} \mathrm{dry}$ weight) with most values $>200 \mathrm{\mu g} \mathrm{g}^{-1}$ dry weight in the Humber and some $>300 \mu \mathrm{g} \mathrm{g}^{-1}$ dry weight in the Mersey. Many more nauplii hatched from incubated sediments from the Exe than from the more polluted estuaries in April, June and November but larger numbers of nauplii hatched from the samples from the Mersey than from the Exe in October. Eggs were extracted from the samples taken in October and November and incubated; $92 \%$ of those from the Exe, $48 \%$ of those from the Humber and $14 \%$ of those from the Mersey hatched. This is consistent with reduction in viability of eggs with increased pollution. The viability of copepod eggs from sediments appears to have potential as a technique for in situ bioassay of fine sediments.
\end{abstract}

KEY WORDS: Calanoid $\cdot$ Egg $\cdot$ Viability $\cdot$ Sediment $\cdot$ Estuaries $\cdot$ Pollution

\section{INTRODUCTION}

Crustaceans, particularly calanoid copepods, are usually dominant components of inshore and estuarine holozooplankton (Williams \& Collins 1986, Bakker \& van Rijswijk 1994). Most dominant neritic and estuarine calanoid copepods produce eggs, which can remain dormant in the sediments (Marcus 1996). Zooplankton eggs can remain in the sediments usually for periods of days to months and some eggs may remain viable over decades (Marcus et al. 1994). Contaminants and excess organic material settle from the water column in fine sediments in which the eggs also accumulate (Uye et al. 1984). The decomposition of organic matter causes anoxia and generates sulphide. Reductions in viability of calanoid copepod eggs in sediments have been attributed to anoxia, sulphide and toxins (e.g. Uye et al. 1984, Naess 1991, Marcus et al. 1997).

\footnotetext{
•E-mail: jal@wpo.nerc.ac.uk
}

There is, therefore, considerable potential for adverse effects being caused by toxic chemicals and/or increased anoxia. However, calanoid eggs that survive in sediments also survive passage through the guts of predators (Marcus 1984, Conway et al. 1994), indicating a resistance to chemical stress.

Field studies were conducted to determine numbers of nauplii hatching from sediment samples and percentage egg viability at sites on 3 estuaries in the UK, the Exe, the Humber and the Mersey. The concentration of polycyclic aromatic hydrocarbons (PAHs) in the sediment was determined as an index of industrial pollution. The Exe estuary has a relatively low background level of urban and agricultural pollution and a site containing numerous copepod eggs has been identified (George \& Lindley 1997). Samples from this site have been used as controls for work on the more heavily polluted estuaries and to provide material for laboratory experiments with toxins. The results of one set of laboratory experiments were directly relevant to interpretation of the field studies and are briefly 
described here. The catchment areas of the Humber and Mersey include industrial areas of central and northern England and petrochemical works, as well as other industry, and large urban areas are situated on the estuaries. The biological quality of the intertidal zone of the Humber is rated as good (National Rivers Authority 1994). The Mersey has been heavily polluted for over a century. Despite reductions in discharges of contaminants, the intertidal zone of the estuary is still classified as of poor or bad environmental quality (National Rivers Authority 1995).

The work was part of a research programme to investigate the effects of sediment contamination on the viability of zooplankton eggs. The comparison of egg viability between the 3 estuaries was designed to determine whether there was evidence for reduced viability due to pollution in industrialised estuaries.

\section{MATERIALS AND METHODS}

The locations of the 3 estuaries are shown in the map of the southern part of Great Britain (Fig. 1a). Intertidal sediment samples from near mid-tide level were taken at 9 sites as follows -4 sites on the Mersey: 1, Hale Point, 2, Spike Island (Widnes), 3, Eastham Locks and 4. Stanlow (Fig 1b); 1 site on the Exe: 5, West Muds (Fig. 1C); and 4 sites on the Humber: 6, Skeffling, 7, Saltend, 8, Killingholme and 9, Pyewipe (Fig. 1d). Sites 1, 2 and 3 were sampled on 20 June and 4 October, Site 4 on 21 June and 5 October 1995. Site 5 was sampled for laboratory experiments on 15 February 1994 and for comparisons with other estuaries on 25 April, 22 June, 6 October, 22 November and 28 November 1995. Samples were taken at Site 6 on 8 April and 16 November, at Sites 7, 8 and 9 on 12 April and at Site 7 on 15 November 1995. At Site 7 samples were taken on the lower shore and from the banks of a creek on the upper shore as well as at mid-tide level. In all cases the samples were taken within $3 \mathrm{~h}$ of low tide when the areas were exposed.

Pentachlorophenol (PCP), an extensively used biocide known to occur in estuaries (e.g. van Zoest \& van Eck 1991, National Rivers Authority 1995), was selected for experiments on the effects of a toxin on eggs in the sediment. The experiment was carried out with a starting $\left(t_{0}\right)$ concentration of $4 \mu \mathrm{g} \mathrm{l}^{-1}$ (plus $0.005 \%$ acetone solvent carrier).

Sediment from Site 5 for laboratory experiments was sampled using a $19 \mathrm{~mm}$ diameter core tube as described by George \& Lindley (1997). Five samples which had been incubated for $24 \mathrm{~h}$ under PCP solution were washed with filtered sea water (FSW), flowing at approximately $21 \mathrm{~min}^{-1}$, through a $50 \mu \mathrm{m}$ mesh for 1,2 , 3,4 and 5 min. After 2 min no PCP was detected in

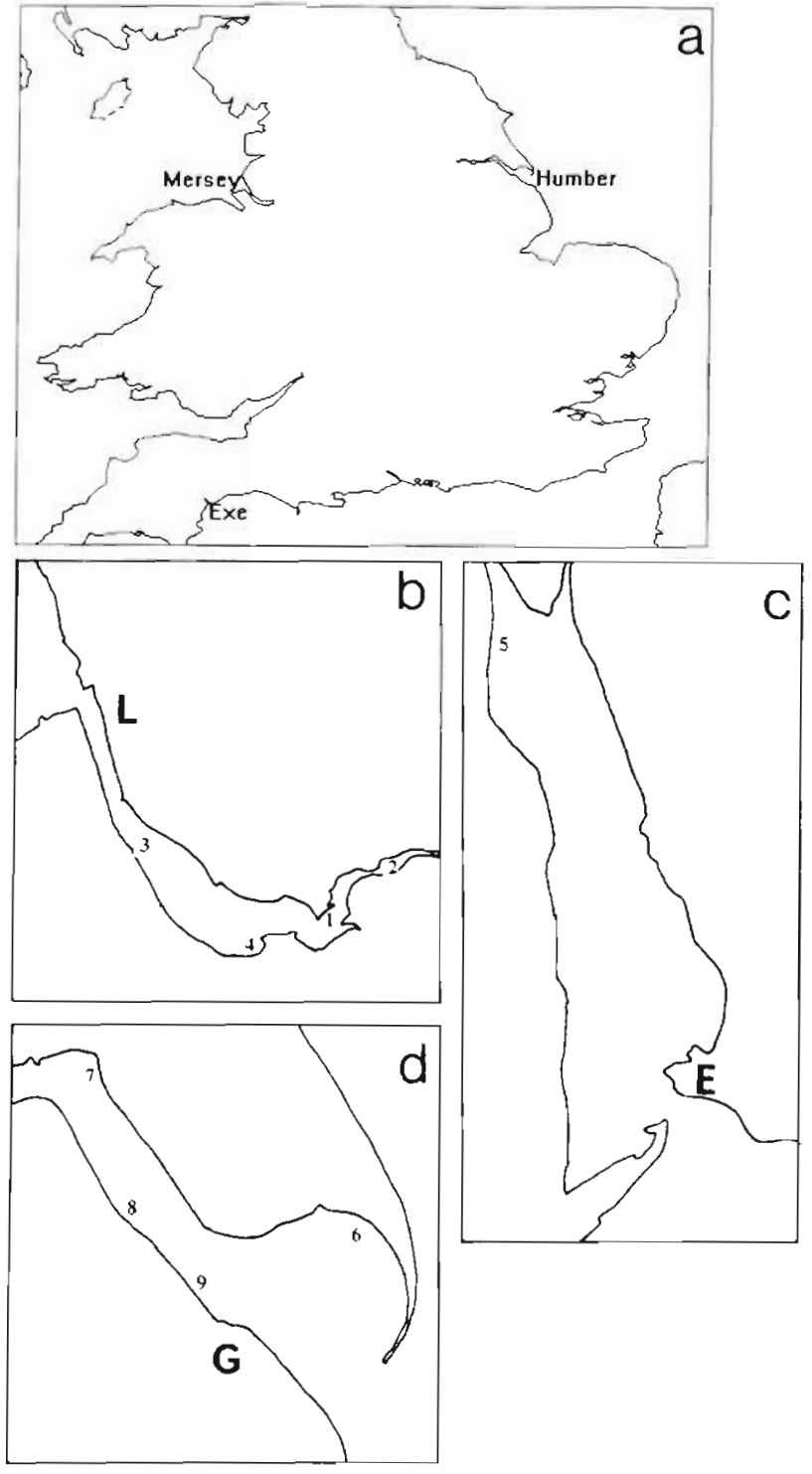

Fig. 1. Sample locations. (a) Southern Britain showing the positions of the Mersey, Humber and Exe estuaries. (b) The Mersey estuary; $\mathrm{L}=$ Liverpool, Site $1=$ Hale, $2=$ Spike Island (Widnes), $3=$ Eastham Locks, $4=$ Stanlow. (c) The Exe estuary; $\mathrm{E}=$ Exmouth, Site $5=$ West Muds. (d) The Humber estuary,$G=$ Grimsby, Site $6=$ Skeffling, $7=$ Saltend, $8=$ Killing holme, 9 = Pyewipe

spectrophotometric analysis of the water which had washed through the sediment. Thirty sediment samples were incubated at 5 to $7^{\circ} \mathrm{C}$ in the dark under $70 \mathrm{ml}$ of PCP solution and an equal number were incubated under FSW (with $0.005 \%$ acetone) as controls. After periods of $1,2,4,8$ and $16 \mathrm{~d}$, the PCP concentration in the supernatant solution was measured and 5 samples which had been incubated under PCP solution and 5 controls were washed through a $50 \mu \mathrm{m}$ mesh for $3 \mathrm{~min}$. The sediment retained by the mesh was incubated at 
$15^{\circ} \mathrm{C}$. At intervals of 3 to $4 \mathrm{~d}$ the water was poured off, preserved and calanoid nauplii were counted. The FSW over the sediment was renewed. This was repeated until no further nauplii had been found for at least $1 \mathrm{wk}$. Numbers of nauplii recovered from the PCP-treated sediment and the controls were compared and percentage mortality due to exposure to PCP was calculated from the differences between the 2 sets of replicates, Lindley et al. (1997) give further details of this and other experiments on eggs and sediments with $\mathrm{PCP}$ and 1,2-dichlorobenzene (DCB).

For the comparison of sediments from the 3 estuaries, samples $(\sim 100 \mathrm{ml}$ in $125 \mathrm{ml}$ jars $)$ were taken, usually at about $5 \mathrm{~m}$ intervals, at each site from the aerobic layer (not discoloured, usually 0 to $3 \mathrm{~cm}$ depth). In April and June further samples were taken from a deeper, anaerobic (black, usually 3 to $6 \mathrm{~cm}$ ) level. The aerobic layer was sampled by scraping up sediment evenly distributed vertically through the non-discoloured layer. This layer was then cleared from an area to expose discoloured anaerobic sediment, which was sampled in the same way.

The sediments from these locations were analysed using steam distillation (Donkin \& Evans 1984) and spectrofluorimetry to determine the polycyclic aromatic hydrocarbon (PAH) content. Sediment samples (6 $\mathrm{g}$ wet weight) were steam distilled from aqueous alkali for $14 \mathrm{~h}$ with $10 \mathrm{ml}$ of 2,2,4-trimethylpentane (TMP). No acidification step was required prior to distillation. The extracts were stored at $-17^{\circ} \mathrm{C}$ for more than $12 \mathrm{~h}$ to remove water, diluted 10 -fold in TMP, then the fluorescence determined by synchronous scanning between 250 and $500 \mathrm{~nm}$ using a Perkin Elmer LS 50B luminescence spectrometer (cf. Phillips et al. 1987). The scanning wavelength differential was $23 \mathrm{~nm}$ and both excitation and emission slits were set at $5 \mathrm{~nm}$. Quantification was by reference to commercially available diesel oil (Jet Automotive) at a wavelength of $301.1 \mathrm{~nm}$. Sediment sample distillates all had a distinct peak at this wavelength, which is characteristic of diaromatic compounds. Under these analytical conditions, 1 unit (by weight) of Jet diesel oil dissolved in TMP gave the same fluorescence signal as 0.84 units of pure 2,3-dimethylnaphthalene dissolved in TMP.

Sediment dry weights were determined after oven drying samples of approximately $6 \mathrm{~g}$ wet weight (the weight was determined accurately in each case) in evaporating dishes at $80^{\circ} \mathrm{C}$ for $24 \mathrm{~h}$. The samples were then dried for a further $24 \mathrm{~h}$ and re-weighed to ensure there had been no further loss of water. Ash weights were determined by heating the dry sediment samples at $450^{\circ} \mathrm{C}$ for $24 \mathrm{~h}$. The ratios between dry and wet weight and between ash and dry weights were used to characterise the sediments. The former is a measure of water content (fine sediments retaining more water than coarse sediments), and the latter gives an inverse measure of organic content.

Three procedures were used to study hatching of the naupli1

(1) Sub-samples $\left(-10 \mathrm{~cm}^{3}\right)$ of sediment were incubated under $70 \mathrm{ml} F S W$ in $100 \mathrm{ml}$ beakers in constant artificial light at $20^{\circ} \mathrm{C}$. The numbers of nauplii recovered from the supernatant were counted every 2 to $5 \mathrm{~d}$ (usually 3 to $4 \mathrm{~d}$ ) as described above. This incubation of the untreated sediment was to obtain an estimate of the numbers likely to hatch from the sediment in the event of only limited disturbance (e.g. normal tidal flushing).

(2) Sediment sub-samples of equivalent size $\left(\sim 10 \mathrm{~cm}^{3}\right)$ were washed through a $50 \mu \mathrm{m}$ mesh gauze, the material retained by the gauze was then incubated at $20^{\circ} \mathrm{C}$ and the numbers of calanoid nauplii hatching from each sub-sample were determined as described above. By thorough aeration, cleaning of the sediment and removal of finer particles, this provides a measure of the maximum hatch in the event of complete resuspension of the eggs in clean seawater.

(3) Eggs were extracted by the sucrose extraction method (Onbé 1978). Sub-samples of $-10 \mathrm{~cm}^{3}$ of sediment were washed through a $200 \mu \mathrm{m}$ mesh gauze and a $50 \mu \mathrm{m}$ mesh gauze. The former strains out larger particles in the sediment, the copepod eggs and similarly sized particles remain on the latter while fine sediment is washed away. The material remaining on the finer gauze was then re-suspended in a 1:1 solution of sucrose in water. This suspension was centrifuged at $950 \times g$ for $5 \mathrm{~min}$. After centrifugation the supernatant was washed through $50 \mu \mathrm{m}$ mesh gauze with filtered seawater and the material retained on the gauze was washed into a Petri dish, where intact eggs with contents apparently consistent with normal development were counted. The eggs were incubated in the Petri dishes under FSW at $20^{\circ} \mathrm{C}$ in constant light. The dishes were examined and nauplii were counted and removed at intervals of 2 to $5 \mathrm{~d}$ (usually 3 or $4 \mathrm{~d}$ ). The numbers of nauplii that hatched as a percentage of eggs present gave a measure of the percentage of viable eggs among those extracted from sediment.

Sediments sampled in April and June 1995 were incubated unwashed (treatment 1) and washed (treatment 2). Sucrose extractions (treatment 3) were not carried out immediately but were carried out subsequently using frozen samples to determine the number of eggs present. Freezing kills calanoid eggs (Naess 1991) so eggs extracted from these samples were not incubated. In October and November only aerobic samples were taken but eggs extracted as soon as the samples had been returned to the laboratory were incubated concurrently with the washed and unwashed sediments. The differences between the estu- 
Table 1. Calanoid nauplii. Mean numbers hatching from sediment samples washed and incubated at $15^{\circ} \mathrm{C}$ following incubation for 1 to $16 \mathrm{~d}$ under filtered sea water (FSW) or pentachlorophenol solution (PCP) at 5 to $7^{\circ} \mathrm{C}$ in the dark. Means are calculated from 5 replicates. Standard deviations are given in parentheses. Percentage mortality (\% mort.) due to PCP is calculated from the difference between the treatments

\begin{tabular}{|lccccc}
\hline & \multicolumn{5}{c}{ Days } \\
& 1 & 2 & 4 & 8 & 16 \\
\hline FSW & $12.6(6.3)$ & $7.8(3.0)$ & $10.0(4.5)$ & $6.8(4.3)$ & $0.8(0.8)$ \\
PCP & $9.6(5.7)$ & $3.2(1.8)$ & $5.2(4.4)$ & $0.8(1.3)$ & 0 \\
$\%$ mort. & 23.8 & 59.0 & 48.0 & 88.2 & 100 \\
\hline
\end{tabular}

aries in numbers of nauplii hatched from the sediments and the percentage hatch from extracted eggs were compared by means of $t$-tests.

\section{RESULTS}

The results of the experiment to determine the effects of PCP are given in Table 1. The mean numbers hatching from the PCP-treated samples were lower than the controls throughout. Values of $t$ showed that the differences after 2 and $8 \mathrm{~d}$ were significant. With the exception of lower percentage mortality after $4 \mathrm{~d}$ than after $2 \mathrm{~d}$ the percentage mortality increased with duration of exposure. PCP concentrations in the beakers fell to $46.6 \%$ of the initial concentration after $1 \mathrm{~d}$ and subsequent measurements fell within the range 38.6 to $58 \%$ with no trend in relation to time.

The dry weights as a percentage of wet weights and the ash weights as a percentage of dry weights of sediment samples are given in Table 2. Water content was just under half of the wet weight of the samples from
Site 5 and the organic content comprised about $5 \%$ of the dry weight. The sediments from Sites 4 and 9 , the aerobic layer of Sites 2 and 8 and the samples from Site 6 in November had substantially higher water and organic content than those from Site 5. Dry and ash weight data from separate sediment samples taken at the same site fell within a standard deviation of 0.4 to $7.5 \%(\mathrm{n}=3)$. The hydrocarbon (PAH) concentrations in the sediments are listed in Table 3. Replicated PAH analyses of the same sediment sample fell within $\pm 5 \%$. Analysis of different cores from the same site fell within a relative standard deviation of 5 to $25 \%(n=3)$.

The values for Sites 6 to 9 on the Humber were mainly 2 to 3 times values for Site 5 (the Exe). The PAH values for samples from Sites 1,2 and 4 were comparable with or higher than those from the Humber with lower values at Site 3 in October. Overall PAH concentrations were highest on the Mersey and lowest on the Exe.

Table 4 gives the numbers of nauplii recovered from incubations of sediments from the Humber and Exe in April 1995 and the Mersey and the Exe in June 1995. Fewer nauplii hatched from the sediments from the Humber in April and the Mersey in June than from the corresponding Exe sediments for those months. In all cases $t$-tests demonstrated significant differences between the Exe and each site on the other estuaries for which $t$ could be calculated and the combined results for all sites on the other 2 estuaries (Humber/Exe, $t=$ 3.31, $\mathrm{p}<0.01$, Mersey/Exe, $t=4.11, \mathrm{p}<0.001)$. More nauplii hatched from anaerobic than from aerobic washed samples from Sites 5 and 6 in April and Site 4 in June. In all other cases the aerobic samples were more productive.

Nauplii were not routinely identified although it was noted that Acartia spp. were dominant with Temoridae

Table 2. Dry weight/wet weight (d/w) $(\%)$ and ash weight/dry weight (a/d) $(\%)$ of aerobic $(\sim 0$ to $3 \mathrm{~cm}$ depth) sediments from sites from the Mersey (June and October 1995). Exe (April, June and November 1995) and Humber estuaries (April and November 1995). Values in parentheses are from anaerobic sediments $(\sim 3$ to $6 \mathrm{~cm}$ depth $)$

\begin{tabular}{|c|c|c|c|c|c|c|c|c|}
\hline \multirow[t]{2}{*}{ Estuary/Site } & \multicolumn{2}{|c|}{ April } & \multicolumn{2}{|c|}{ June } & \multicolumn{2}{|c|}{ October } & \multicolumn{2}{|c|}{ November } \\
\hline & $\mathrm{d} / \mathrm{w}$ & $a / d$ & $d / w$ & $\mathrm{a} / \mathrm{d}$ & $d / w$ & $a / d$ & $\mathrm{~d} / \mathrm{w}$ & $a / d$ \\
\hline \multicolumn{9}{|l|}{ Mersey } \\
\hline 1 & & & $41.6(53.4)$ & $94.5(95.3)$ & & & & \\
\hline 2 & & & $37.4(66.4)$ & $92.6(94.5)$ & & & & \\
\hline 3 & & & $50.0(59.5)$ & $94.3(93.5)$ & 54.9 & 96.7 & & \\
\hline 4 & & & $39.4(44.6)$ & $90.8(90.6)$ & 34.3 & 90.3 & & \\
\hline \multicolumn{9}{|l|}{ Exe } \\
\hline 5 & $50.0(57.1)$ & $95.6(95.2)$ & $52.2(55.6)$ & $94.2(95.5)$ & & & 49.9 & 95.2 \\
\hline \multicolumn{9}{|l|}{ Humber } \\
\hline 6 & $60.5(59.2)$ & $92.3(93.6)$ & & & & & 41.7 & 87.3 \\
\hline 7 & $49.1(48.2)$ & $94.3(93.6)$ & & & & & 48.5 & 92.5 \\
\hline 8 & $32.6(52.6)$ & $91.6(94.8)$ & & & & & & \\
\hline 9 & $29.3(39.5)$ & $89.3(90.7)$ & & & & & & \\
\hline
\end{tabular}


Table 3. Polycyclic aromatic hydrocarbon content (PA.H) of aerobic ( $\sim 0$ to $3 \mathrm{~cm}$ depth) sediments from the Mersey (June and October 1995), Exe (April, June and November 1995) and Humber estuaries (April and November 1995). Values in parentheses are values for anaerobic sediment 3 to $6 \mathrm{~cm}$ depth)

\begin{tabular}{|c|c|c|c|c|}
\hline \multirow[t]{2}{*}{ Estuary/Site } & \multicolumn{4}{|c|}{ PAH ( $\mu g g^{-1}$ dry weight) } \\
\hline & April & June & October & November \\
\hline \multicolumn{5}{|l|}{ Mersey } \\
\hline 1 & & $297(349)$ & & \\
\hline 2 & & $285(163)$ & & \\
\hline 3 & & $191(211)$ & & 135 \\
\hline 4 & & $315(326)$ & & 344 \\
\hline \multicolumn{5}{|l|}{ Exe } \\
\hline 5 & $83(90)$ & $77(105)$ & & 94 \\
\hline \multicolumn{5}{|l|}{ Humber } \\
\hline 6 & $195(210)$ & & 215 & \\
\hline 7 & 233 (215) & & 241 & \\
\hline 8 & $283(186)$ & & & \\
\hline 9 & $283(285)$ & & & \\
\hline
\end{tabular}

(mainly Temora longicornis) and Centropages spp. (probably mainly C. hamatus) also present.

Eggs were extracted from 3 frozen samples from Site 7 (16, 13 and 10 calanoid eggs respectively) and 2 from Site 5 in April ( 15 and 22 eggs respectively). Eggs were extracted from a frozen sample from each site sampled in June. Forty calanoid eggs were extracted from Site 5; the samples from the Mersey yielded 17 , 79,39 and 81 calanoid eggs from Sites 1 to 4 respectively. The similarity between the numbers of eggs in samples from different sites contrasts with the difference between the Exe and the other 2 estuaries in numbers of nauplii recovered from the sediment incubations. The eggs were not routinely identified, but
Table 4. Calanoid nauplii. Numbers hatched per sub-sample $\left(\sim 10 \mathrm{~cm}^{3}\right)$ from Mersey, Humber and Exe sediments taken in April and June 1995. $n=$ number of replicates. Standard deviations are given in parentheses

\begin{tabular}{|c|c|c|c|c|c|}
\hline \multirow{3}{*}{$\begin{array}{l}\text { Estuary' } \\
\text { Site }\end{array}$} & \multirow{3}{*}{$\mathrm{n}$} & \multicolumn{4}{|c|}{ Nauplij hatched per sample } \\
\hline & & \multicolumn{2}{|c|}{ Aerobic } & \multicolumn{2}{|c|}{ Anaerobic } \\
\hline & & Unwashed & Washed & Unwashed & Washed \\
\hline \multicolumn{6}{|c|}{ Mersey (June) } \\
\hline 1 & 5 & 0 & $0.6(0.6)$ & 0 & 0 \\
\hline 2 & 5 & 0 & $2.0(1.2)$ & 0 & $1.2(0.8)$ \\
\hline 3 & 5 & 0 & $3.4(2.5)$ & 0 & $1.4(1.7)$ \\
\hline 4 & 5 & 0 & $0.4(0.9)$ & $0.2\{0.5\}$ & $1.2(1.1)$ \\
\hline \multicolumn{6}{|l|}{ Exe } \\
\hline 5 (April) & 5 & $4.4(2.88)$ & $6.2(4.2)$ & $2.4(1.4)$ & $12.6(6.2)$ \\
\hline 5 (June) & 5 & $9.2(3.83)$ & $48.6(13.4)$ & $4.0(1.6)$ & $24.4(14.3)$ \\
\hline \multicolumn{6}{|c|}{ Humber (April) } \\
\hline 6 & 4 & 0 & $1.5(2.4)$ & 0 & $2.5(2.4)$ \\
\hline 7-lower & 5 & 0 & $0.8(1.1)$ & 0 & 0 \\
\hline 7 -mid & 5 & 0 & $0.8(1.3)$ & 0 & $0.2(0.5)$ \\
\hline 7 -creek & 5 & 0 & $0.4(0.9)$ & $0.2(0.5)$ & $0.2(0.5)$ \\
\hline 8 & 1 & 0 & 6 & 0 & 0 \\
\hline 9 & 1 & 0 & 1 & 0 & 0 \\
\hline
\end{tabular}

Acartia spp. and Temoridae were usually dominant and Centropages hamatus eggs were noted in the samples from the Mersey.

The results of the incubations of sediments and extracted eggs from samples taken in October and November 1995 are presented in Table 5. Significantly higher numbers of nauplii hatched from the sediments from Sites 3 and 4 and from the Mersey as a whole $(t=5.39, \mathrm{p}<0.001)$ than from Site 5 (Exe). However the percentages of eggs extracted from the individual sites ( 1 to 4 ) and from all sites combined on the Mersey which hatched were significantly lower than the equivalent percentages for Site 5 (Exe)

Table 5. Calanoid eggs and nauplii. Nauplii hatched per sample $\left(\sim 10 \mathrm{~cm}^{3}\right)$ from incubated aerobic sediments and from eggs extracted from sediments from the Mersey and the Exe, October 1995 and the Humber and the Exe, November 1995, and mean percentage hatch from extracted eggs. $n=$ number of replicates. Standard deviations are given in parentheses. nd: no data

\begin{tabular}{|c|c|c|c|c|c|c|}
\hline \multirow[t]{2}{*}{ Estuary/Site } & \multirow[t]{2}{*}{$\mathrm{n}$} & \multicolumn{2}{|c|}{ Nauplii hatched per sample } & \multirow[t]{2}{*}{$\mathrm{n}$} & \multirow{2}{*}{$\begin{array}{l}\text { Mean number of } \\
\text { eggs per sample }\end{array}$} & \multirow[t]{2}{*}{$\%$ hatch } \\
\hline & & Unwashed & Washed & & & \\
\hline \multicolumn{7}{|l|}{ Mersey (October) } \\
\hline 1 & 5 & $7.6(2.9)$ & $20.6(9.0)$ & 2 & $82.5(20.5)$ & 25.8 \\
\hline 2 & 5 & $5.0(3.5)$ & $22.4(4.3)$ & 2 & $32.5(20.5)$ & 6.2 \\
\hline 3 & 5 & $49.4(25.7)$ & $69.8(29.4)$ & 2 & $228.5(87.0)$ & 15.5 \\
\hline 4 & 5 & $6.0(3.4)$ & $49.8(13.2)$ & 2 & $146(22.6)$ & 7.9 \\
\hline \multicolumn{7}{|l|}{ Exe } \\
\hline 5 (October) & 5 & $5.2(2.8)$ & $20(9.5)$ & 2 & $5.5(2.1)$ & 90.9 \\
\hline 5 (22 November) & & nd & nd & 5 & $13.8(4.7)$ & 81.2 \\
\hline 5 (28 November) & 5 & $55.8(11.0)$ & $54.5(27.5)$ & 6 & $54.4(24.9)$ & 95.2 \\
\hline \multicolumn{7}{|c|}{ Humber (November) } \\
\hline 6 & 5 & $0.2(0.5)$ & $5.4(3.4)$ & 5 & $5.4(3.8)$ & 66.7 \\
\hline 7 & 5 & $0.2(0.5)$ & $0.6(0.9)$ & 5 & $5.2(2.8)$ & 26.9 \\
\hline
\end{tabular}


Table 6 . Correlation coefficients between dry weight as a percentage of wet weight of sediment, ash weight as a percentage of dry weight of sediment, polycyclic aromatic hydrocarbon content of the sediment (PAH) and percentage hatch from eggs extracted from sediment. The correlation in bold type is significant $(p<0.01)$

\begin{tabular}{|lccc|}
\hline & Ash/dry $(\%)$ & PAH $\left(\mu g^{-1}\right)$ & Hatch $(\%)$ \\
\hline Dry/wet $(\%)$ & 0.400 & -0.556 & 0.236 \\
Ash/dry $(\%)$ & & $-\mathbf{0 . 8 5 6}$ & 0.317 \\
PAH $\left(\mu \mathrm{g} \mathrm{g}^{-1}\right)$ & & & -0.661 \\
\hline
\end{tabular}

I $t=9.201, \mathrm{p}<0.001$ for the comparison between Sites 1 to 4 combined and Site 5). Fewer nauplii hatched from sediments from the Humber than from the Mersey, but the percentage of eggs hatching from Site 7 was comparable with the best result from the Mersey (Site 1). At Site 6 the percentage was intermediate between the results from the Mersey and those from Site 5. The $t$ value (2.238) for the comparison between the percentage hatch from the Humber sites ( $6 \& 7$ ) and the Exe (Site 5) was lower than that for the Mersey/Exe comparison but it was still significant $(\mathrm{p}<$ $0.05)$. Combining the results from all incubations of eggs extracted from the sites on each estuary, the percentages hatching were $14.3 \%$ of 977 eggs from the Mersey, $48.1 \%$ of 54 eggs from the Humber and $92.3 \%$ of 352 eggs from the Exe.

Correlation coefficients were calculated from the sediment characteristics, including PAH content, and the percentage hatch from extracted eggs for each site on the Humber and Mersey and for all samples taken in October and November combined from Site 5. The percentage hatch values used were those derived from the total egg numbers and total hatch from each site. The results in the matrix (Table 6) show that the PAH content of the sediments were significantly negatively correlated with ash weight/dry weight (i.e. positively correlated with organic content of the sediment). The negative correlation coefficient between percentage hatch and PAH content was higher (with $0.1>p>0.05$ ) than the positive coefficients with the other 2 variables.

\section{DISCUSSION}

The 3 estuaries were selected to compare 1 with little industrial pollution (Exe) with 2 estuaries with histories of industrial pollution but with differing levels of impact: the Mersey, where effects of pollution on the intertidal biota were severe, and the Humber, which retains a rich intertidal biota. The PAH values as an index of current contamination confirmed that at the time of sampling the Mersey was the most polluted and the Exe the least polluted of the 3 estuaries.

The percentage of extracted eggs that hatched was lowest in samples from the Mersey and highest in samples from the Exe. The hatching success of eggs extracted from Exe sediments over 3 sampling occasions, with $53 \mathrm{~d}$ between the earliest and latest samples, was greater than that from the other 2 estuaries. The results of sediment incubations and egg counts for the April and June samples add support to the higher viability of eggs in the Exe sediments. Many more nauplii hatched from the samples from the Exe samples than from the other estuaries but the counts of eggs from frozen samples did not show such a contrast. The numbers of calanoid and cladoceran eggs in the sediment in temperate waters reach a maximum at, or just after, the peak of pelagic egg production and a minimum in the spring before the initiation of pelagic egg production (e.g. Kasahara et al. 1975 , Onbé 1991). The similarity in egg counts from the frozen samples suggests that the low numbers of nauplii hatching from the Humber samples taken in April and the Mersey samples taken in June cannot be attributed entirely to such seasonal variations, which should also occur in the Exe. As many eggs in the sediment in the spring would have been there for several months, any adverse factors (anoxia or toxins) in the sediment would have had a substantial period in which to take effect. The combination of the results provides strong evidence that the proportion of viable eggs is reduced in sediments contaminated by industrial and urban pollution.

The intensity of egg production by the calanoids in the plankton in the few days or weeks prior to the sampling were probably responsible for much of the variation in numbers of nauplii hatching from samples from the same sites at different dates. There are no data on egg production from the estuaries at the time of these studies. The high numbers of nauplii hatching from the Mersey samples taken in October and in the later of the 2 sampling occasions on the Exe in November may reflect recent deposition of freshly produced eggs. However, the low percentage hatch from the eggs extracted from the Mersey sediments may have been a result of suppression of hatching over the summer and autumn months by contaminants. This suppression may have been a direct result of contaminants or effects of anoxia, leading to accumulation of eggs, many of which ceased to be capable of successfully completing development despite return to favourable conditions. The similarity between the numbers of nauplii hatched from both the washed and unwashed sediments from the Exe on 28 November and the high $(95.2 \%)$ hatching success from the extracted eggs indicated that the bulk of those eggs were recently 
deposited, allowing little time for anoxia to cause damage. Marcus et al. (1997) found that hatching success under normoxia of subitaneous eggs declined with the length of time during which they were exposed to anoxia. The results presented here indicated a cumulative effect of PCP with time.

It is not known which pollutants were responsible for reducing the viability of eggs in the sediment. Table 5 shows that there is a negative correlation between $\mathrm{PAH}$ content and percentage hatch and the positive correlations with dry weight/wet weight and ash weight/dry weight are much weaker. Oil has been shown to reduce the success of hatching and larval development of calanoids in enclosed experimental ecosystems (Davies et al. 1980). At Site 3, near to the entrance to the Manchester Ship Canal, the percentage hatch from extracted eggs was low (Table 5) despite the PAH content being the lowest from the 2 industrially contaminated estuaries (Table 3). This indicates that, at least at that site, contaminants other than PAHs and toxins highly correlated with their distribution may be responsible for the reduction in viability. Lead concentrations are high in the Manchester Ship Canal discharge and other heavy metals have been deposited in the Mersey in the past (National Rivers Authority 1995). Murray \& Norton (1979) found higher levels of mercury, lead and chromium in dredged spoils from Manchester Ship Canal Docks than in any comparable material from 45 other locations and high levels of copper, zinc, cadmium and nickel were also present. Hatching and naupliar development of calanoids are very sensitive to heavy metals in the seawater (Davies 1978) so high concentrations of heavy metals in the Manchester Ship Canal discharge may contribute to the low viability of the eggs in the sediment.

The variations in viability of the eggs in the sediment suggest that these eggs could be used for bioassay of sediment quality, at least for the fine sediments in which the eggs can be abundant. The eggs are present in the sediment when it is sampled and have been exposed to the conditions prevailing in the sediment in situ. Strict comparison would require data on the length of time that the eggs had been in the sediment and what effect this would have on mortality. As this may vary between species (e.g. Marcus et al. 1997), specific identification of at least a sub-sample of eggs should ideally be included. Wherever possible, geographically proximate and hydrographically similar sites with contrasting contaminant loads should be compared to ensure that 'control' samples are as similar as possible to samples from polluted sites in species composition, recent history of pelagic egg production, sediment characteristics, temperature and salinity.
Acknowledgements. This work was carried out under a contract (Reference number EPG 1/9/01) from the UK Department of the Environment to study the effects of sediment contamination on zooplankton eggs. It is part of the PML Strategic Research Programmes on coastal biodiversity and stress effects and health in the oceans. Dr D. Plummer and Mrs P. E. Frickers gave valuable help with sampling on the Humber. Mr A. Grant assisted with the egg extractions. We thank referees for their comments.

\section{LITERATURE CITED}

Bakker C, van Rijswijk P (1994) Zooplankton biomass in the Oosterschelde (SW Netherlands) before, during and after the construction of a storm surge barrier. Hydrobiologia 282/283:127-143

Conway DVP, McFadzean IRB, Tranter PRG (1994) Digestion of copepod eggs by larval turbot Scophthalmus maximus and egg viability following gut passage. Mar Ecol Prog Ser 106:303-309

Davies AG (1978) Pollution studies with marine plankton. Part II. Heavy metals. Adv Mar Biol 15:382-508

Davies JM, Baird IE, Massie LC, Hay SJ, Ward AP (1980) Some effects of oil derived hydrocarbons on a pelagic food web from observations in an enclosed ecosystem and a consideration of their implications for monitoring. Rapp PV Réun Cons Int Explor Mer 179:201-211.

Donkin P, Evans SV (1984) Application of steam distillation in the determination of petroleum hydrocarbons in water and mussels (Mytilus edulis) from dosing experiments with crude oil. Anal Chim Acta 156:207-219

George CL, Lindley JA (1997) Hatching of nauplii of calanoid copepods from intertidal estuarine sediments. J Mar Biol Assoc UK 77:249-252

Kasahara S, Uye S, Onbé T (1975) Calanoid copepod eggs in sea bottom muds. II. Seasonal cycles of abundance in the populations of several species of copepods and their eggs in the Inland Sea of Japan. Mar Biol 31:25-29

Lindley JA, Donkin P. George CL, Evans SV (1997) The effect of sediment contamination on the viability of zooplankton eggs. Report to Department of Environment, Transport and the Regions on Research Contract EPG 1/9/01, Plymouth Marine Laboratory, Plymouth

Marcus NH (1984) Recruitment of copepod nauplii into the plankton: importance of diapause eggs and benthic processes. Mar Ecol Prog Ser 15:47-54

Marcus NH (1996) Ecological and evolutionary significance of resting eggs in marine copepods: past present and future studies. Hydrobiologia 320:141-152

Marcus NH, Lutz R, Burnett W, Cable P (1994) Age, viability, and vertical distribution of zooplankton resting eggs from an anoxic basin: evidence of an egg bank. Limnol Oceanogr 39:154-158

Marcus NH, Lutz RV, Chanton JP (1997) Impact of anoxia and sulphide on the viability of eggs of three planktonic copepods. Mar Ecol Prog Ser 146:291-295

Murray LA, Norton MG (1979) The composition of dredged spoils dumped at sea from England and Wales. Fish Res Tech Rep 52:1-10

Naess T (1991) Tolerance of marine calanoid resting eggs: effects of freezing, desiccation and Rotenone exposurea field and laboratory study. Mar Biol 111:455-459

National Rivers Authority (1994) Humber Estuary quality report 1993. Humber Estuary Committee of the National Rivers Authority, Hull

National Rivers Authority (1995) The Mersey Estuary; a 
report on environmental quality. HMSO, London

Onbé T (1978) Sugar floatation method for sorting the resting eggs of marine cladocerans and copepods from sea bottom sediments. Bull Jpn Soc Sc1 Fish 44:1411

Onbé T (1991) Some aspects of the biology of marine cladocerans. In: Wenner A, Kuris A (eds) Crustacean egg production. AA Balkema, Rotterdam, p 41-55

Phillips CR, Payne JR, Lambach JL, Farmer GH, Sims RR Jr (1987) Georges bank monitoring program: hydrocarbons in bottom sediments and hydrocarbons and trace metals in tissues. Mar Environ Res 22:33-74

Editorial responsibility: Otto Kinne (Editor).

Oldendorf/Luhe, Germany
Van Zoest R, Van Eck GTM (1991) Occurence and behaviour of several groups of organic micropollutants in the Scheldt estuary. Sci Tot Environ 103:57-71

Uye SI, Yoshiya M, Ueda K, Kasahara S (1984) The effect of organic sea-bottom pollution on survivability of resting eggs of neritic calanoids. Crustaceana Suppl 7:390-403

Williams R, Collins NR (1986) Seasonal composition of meroplankton and holoplankton in the Bristol Channel. Mar Biol 92:93-101

Williamson DI (1956) The plankton in the Irish Sea 1951 and 1952. Bull Mar Ecol 4:87-144

Submitted: March 26, 1997; Accepted: December 10, 1997

Proofs received from author(s): January 22, 1998 